NASA/TM-2008-215040

ARL-TR-4368
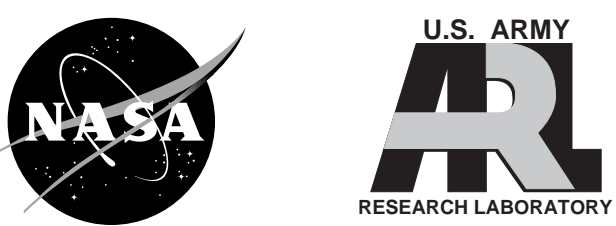

\title{
Thermal and Environmental Barrier Coating Development for Advanced Propulsion Engine Systems
}

Dongming Zhu

U.S. Army Research Laboratory, Glenn Research Center, Cleveland, Ohio

Robert A. Miller and Dennis S. Fox

Glenn Research Center, Cleveland, Ohio 


\section{NASA STI Program . . . in Profile}

Since its founding, NASA has been dedicated to the advancement of aeronautics and space science. The NASA Scientific and Technical Information (STI) program plays a key part in helping NASA maintain this important role.

The NASA STI Program operates under the auspices of the Agency Chief Information Officer. It collects, organizes, provides for archiving, and disseminates NASA's STI. The NASA STI program provides access to the NASA Aeronautics and Space Database and its public interface, the NASA Technical Reports Server, thus providing one of the largest collections of aeronautical and space science STI in the world. Results are published in both non-NASA channels and by NASA in the NASA STI Report Series, which includes the following report types:

- TECHNICAL PUBLICATION. Reports of completed research or a major significant phase of research that present the results of NASA programs and include extensive data or theoretical analysis. Includes compilations of significant scientific and technical data and information deemed to be of continuing reference value. NASA counterpart of peer-reviewed formal professional papers but has less stringent limitations on manuscript length and extent of graphic presentations.

- TECHNICAL MEMORANDUM. Scientific and technical findings that are preliminary or of specialized interest, e.g., quick release reports, working papers, and bibliographies that contain minimal annotation. Does not contain extensive analysis.

- CONTRACTOR REPORT. Scientific and technical findings by NASA-sponsored contractors and grantees.
- CONFERENCE PUBLICATION. Collected papers from scientific and technical conferences, symposia, seminars, or other meetings sponsored or cosponsored by NASA.

- SPECIAL PUBLICATION. Scientific, technical, or historical information from NASA programs, projects, and missions, often concerned with subjects having substantial public interest.

- TECHNICAL TRANSLATION. Englishlanguage translations of foreign scientific and technical material pertinent to NASA's mission.

Specialized services also include creating custom thesauri, building customized databases, organizing and publishing research results.

For more information about the NASA STI program, see the following:

- Access the NASA STI program home page at http://www.sti.nasa.gov

- E-mail your question via the Internet to help@sti.nasa.gov

- Fax your question to the NASA STI Help Desk at 301-621-0134

- Telephone the NASA STI Help Desk at 301-621-0390

- Write to: NASA Center for AeroSpace Information (CASI) 7115 Standard Drive Hanover, MD 21076-1320 
NASA/TM-2008-215040

ARL-TR-4368
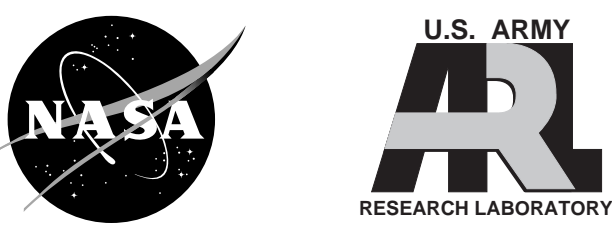

\section{Thermal and Environmental Barrier Coating Development for Advanced Propulsion Engine Systems}

Dongming Zhu

U.S. Army Research Laboratory, Glenn Research Center, Cleveland, Ohio

Robert A. Miller and Dennis S. Fox

Glenn Research Center, Cleveland, Ohio

Prepared for the

48th Structures, Structural Dynamics, and Materials Conference

sponsored by the AIAA, ASME, ASCE, AHS, and ASC

Waikiki, Hawaii, April 23-26, 2007

National Aeronautics and

Space Administration

Glenn Research Center

Cleveland, Ohio 44135 


\section{Acknowledgments}

This work was supported by NASA Ultra-Efficient Engine Technology (UEET) Program and NASA Fundamental Aeronautics (FA) Program Supersonics Project.

Level of Review: This material has been technically reviewed by technical management.

Available from

NASA Center for Aerospace Information 7115 Standard Drive

Hanover, MD 21076-1320
National Technical Information Service 5285 Port Royal Road Springfield, VA 22161

Available electronically at http://gltrs.grc.nasa.gov 


\title{
Thermal and Environmental Barrier Coating Development for Advanced Propulsion Engine Systems
}

\author{
Dongming Zhu \\ U.S. Army Research Laboratory \\ Glenn Research Center \\ Cleveland, Ohio 44135 \\ Robert A. Miller and Dennis S. Fox \\ National Aeronautics and Space Administration \\ Glenn Research Center \\ Cleveland, Ohio 44135
}

\begin{abstract}
Ceramic thermal and environmental barrier coatings (TEBCs) are used in gas turbine engines to protect engine hot-section components in the harsh combustion environments, and extend component lifetimes. Advanced TEBCs that have significantly lower thermal conductivity, better thermal stability and higher toughness than current coatings will be beneficial for future low emission and high performance propulsion engine systems. In this paper, ceramic coating design and testing considerations will be described for turbine engine high temperature and high-heat-flux applications. Thermal barrier coatings for metallic turbine airfoils and thermal/environmental barrier coatings for $\mathrm{SiC} / \mathrm{SiC}$ ceramic matrix composite (CMC) components for future supersonic aircraft propulsion engines will be emphasized. Further coating capability and durability improvements for the engine hot-section component applications can be expected by utilizing advanced modeling and design tools.
\end{abstract}

\section{Introduction}

Ceramic TEBCs are considered technologically important because of their ability to increase gas turbine engine operating temperatures and reduce cooling requirements, thus help achieving engine performance goals. A recent system assessment has shown that the low conductivity turbine coatings provide significant benefits in increasing engine efficiency and reducing $\mathrm{NO}_{\mathrm{X}}$ emissions for various classes of vehicles among the major engine technologies considered (refs. 1 and 2). The advantages of using TEBCs include higher engine efficiency by increasing gas temperatures, and improved engine reliability by reducing engine hot-section component temperatures. The development of advanced ceramic barrier coatings is currently aimed at significantly increasing engine operating temperature and simultaneously reducing air cooling, in order to meet future engine lower emission, higher efficiency and improved reliability goals.

For the supersonic vehicles currently envisioned in the NASA Fundamental Aeronautics Program (FA), advanced gas turbine engines will be used to provide high power density thrust during the extended supersonic flight of the aircraft, while meeting stringent emission requirements. Combustor exit temperatures during the supersonic cruise will lead to turbine inlet temperatures around $167{ }^{\circ} \mathrm{C}\left(300^{\circ} \mathrm{F}\right)$ higher than the current state-of-the-art for subsonic engines. Because of the extended supersonic cruise time with very high inlet air temperature, the engine components will experience long-duration operation at high temperatures throughout the cruise portion of the mission. Improved ceramic coating systems are critical to the performance, life and durability of the hot-section components in the engine systems. The development of advanced ceramic thermal and environmental barrier coatings will enable high temperature capable, lightweight engine hot-section components for increased efficiency, reduced emission and long-term durability required by supersonics propulsion systems. 
To take full advantage of the TEBC capability potential, an aggressive design approach —allowing greater temperature reductions through the coating systems and less cooling air to the components - is required whenever possible. The ceramic coating systems must be designed with increased high-temperature stability, lower thermal conductivity, greater toughness and improved thermal stress and erosion resistance. To achieve these performance characteristics, an advanced defect cluster coating design approach will be beneficial (refs. 3 to 7). As shown in figure 1, the development of revolutionary ceramic coatings, combined with improved single crystal Ni-base superalloy and CMC substrates, will result in a step increase in gas turbine engine blade, vane and combustor component temperature capability.

Higher surface temperatures and larger thermal gradients as compared to conventional coating systems are required in advanced TEBC systems. Figure 2 is a schematic diagram showing how advanced ceramic barrier coatings with lower thermal conductivity and better temperature stability will allow the use of thinner coatings to achieve a larger temperature reduction in the higher operating temperature engines.

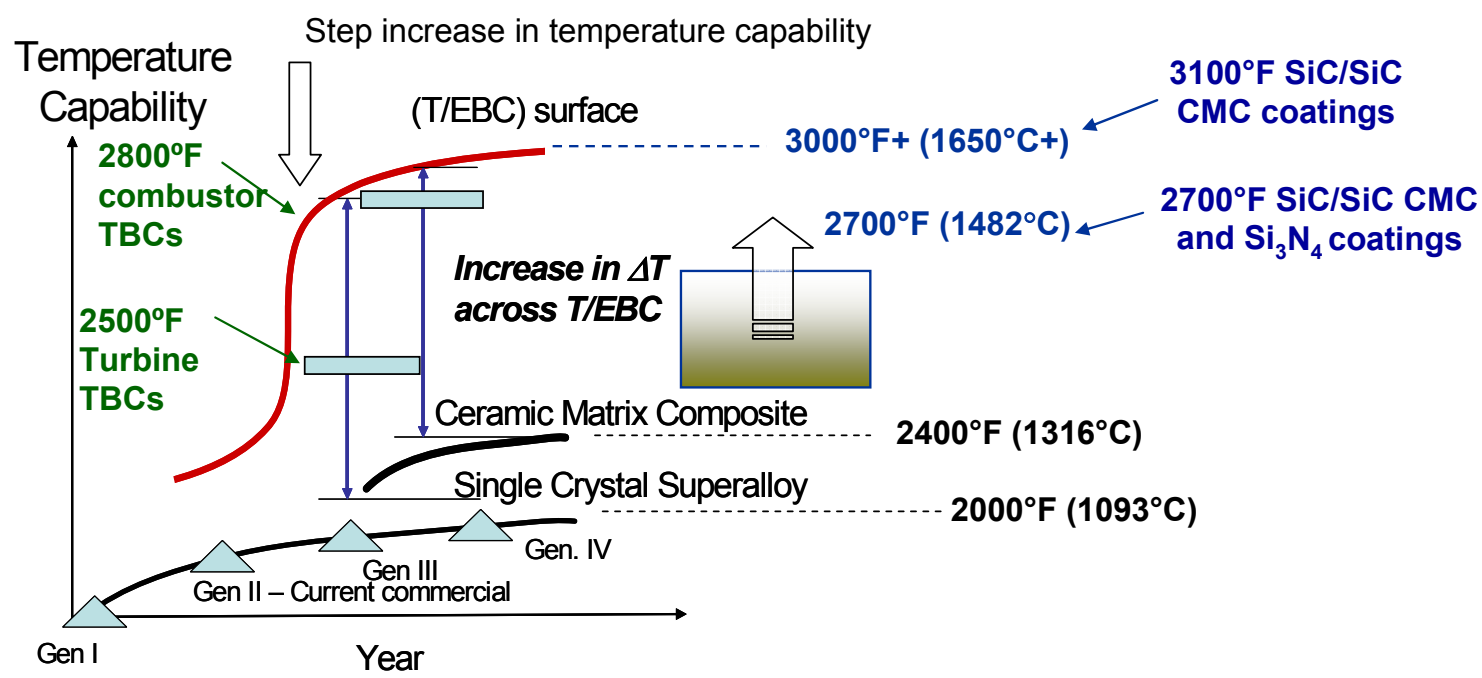

Figure 1.-The development of high temperature stability and low thermal conductivity ceramic coatings, will result in a step increase in the temperature capability of gas turbine hot-section components. The temperature design limits for various classes of materials are shown.

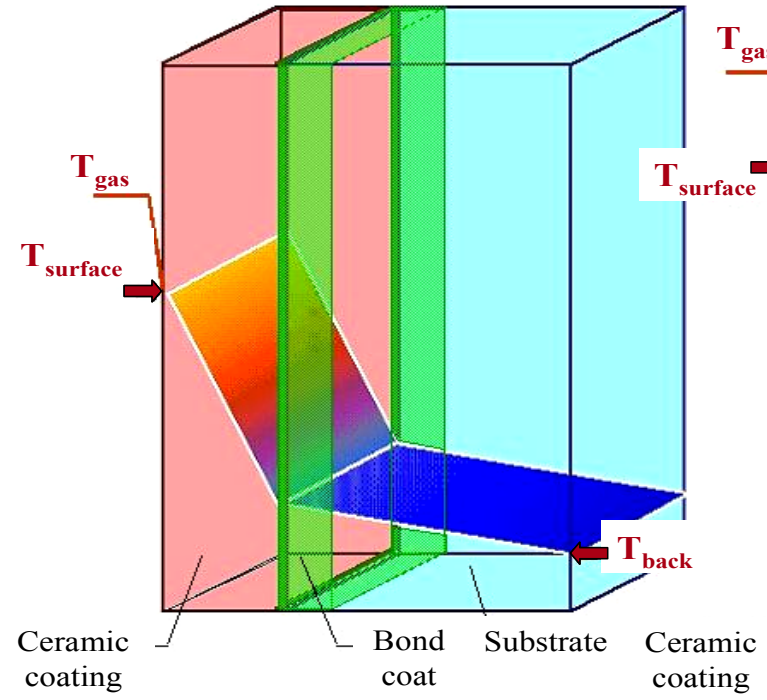

(a)

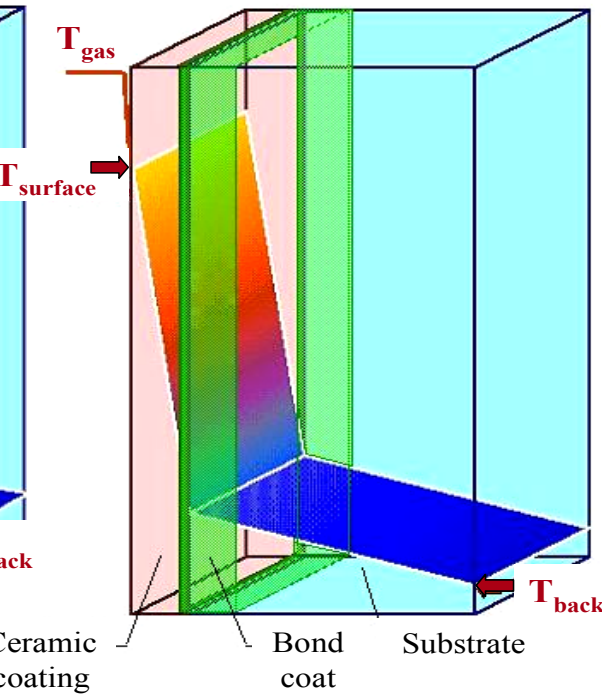

(b)

Figure 2.-Advanced thermal and environmental barrier coatings can significantly increase gas temperatures, reduce cooling requirements, and improve engine fuel efficiency and reliability. (a) Current TEBCs; (b) Advanced TEBCs. 


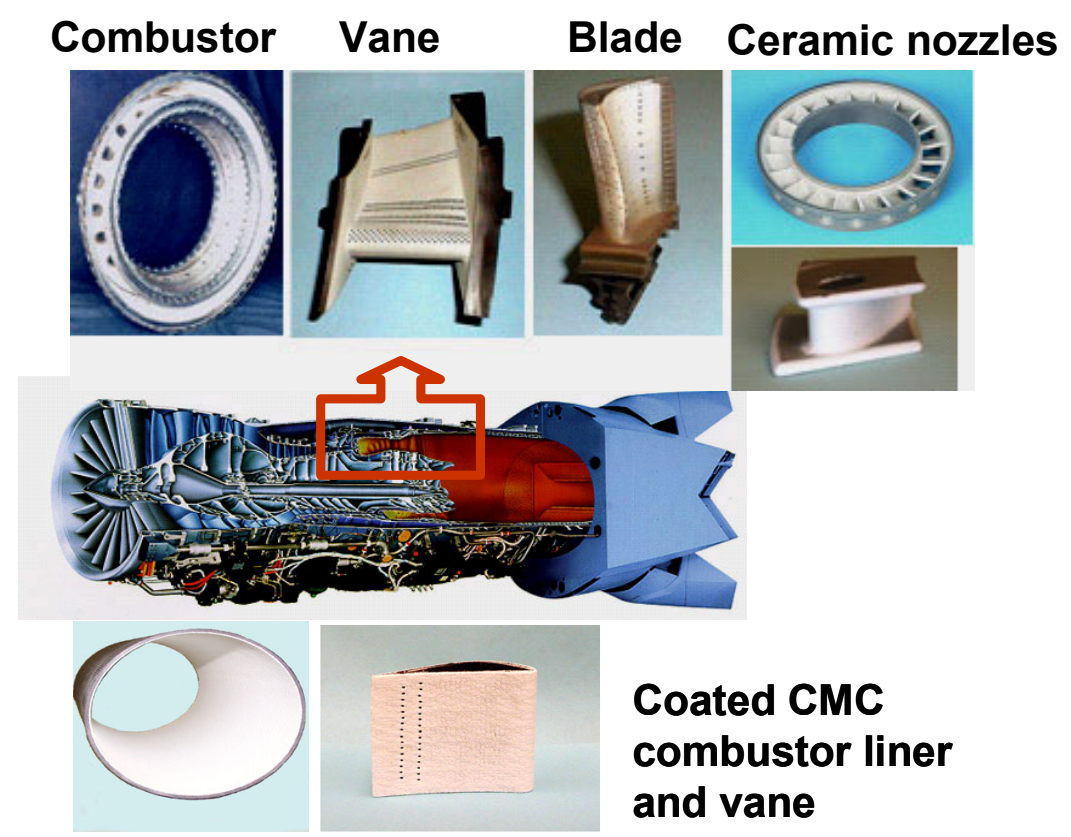

Figure 3.-Ceramic thermal and environmental barrier coatings are critical technologies in future gas turbine engine hot-sections for combustor, vane and turbine airfoil applications.

Figure 3 shows examples of ceramic barrier coatings that are typically used for combustor, vane and turbine airfoil applications. The low conductivity coatings will have a significant advantage over the conventional $\mathrm{ZrO}_{2}-(7-8) \mathrm{wt} \% \mathrm{Y}_{2} \mathrm{O}_{3}$ coatings especially for rotating engine components (such as turbine blades), where a reduced weight is highly desirable. The multi-component doped, oxide alloy defect clustered ceramic TEBC has been shown to offer the low conductivity and high stability required for both high temperature subsonic and supersonic engine applications (refs. 3 to 7). Figure 3 shows the engine hot-section component (combustors, vanes and turbine airfoils) applications for the ceramic thermal and environmental barrier coatings.

In this paper, ceramic coating design and testing considerations are described for engine hot-section component applications in high temperature and high-heat-flux, oxidizing and water vapor-containing combustion environments. Both thermal barrier coatings (TBCs) for metallic turbine blades, and TEBCs for $\mathrm{SiC} / \mathrm{SiC} \mathrm{CMC} \mathrm{combustor} \mathrm{and} \mathrm{turbine} \mathrm{applications,} \mathrm{will} \mathrm{be} \mathrm{emphasized} \mathrm{especially} \mathrm{for} \mathrm{supersonic}$ engines. Coating performance of advanced systems will be discussed. Further improvements will be obtained using new structural designs and composition optimization, in conjunction with modeling and design tools.

\section{Design Approach of Ceramic Defect-Clustering Coatings}

Advanced $\mathrm{ZrO}_{2}$ - and $\mathrm{HfO}_{2}$-based oxide TBCs were designed using a multi-component defectclustering scheme (refs. 3 to 7). The advanced oxide coatings were designed by incorporating multicomponent, paired-cluster dopants in conventional zirconia- and hafnia-yttria oxides. The dopant oxides were selected based on the cation-anion interatomic and chemical potentials, lattice elastic strain energy, polarization and the electro-neutrality of the oxides. Since defect clusters can attenuate and scatter lattice phonon waves as well as radiative photon waves at a wide spectrum of frequencies, one can expect significant reduction in the oxide intrinsic lattice and radiation thermal conductivity. The creation of thermodynamically stable, highly defective lattice structures with controlled ranges of defect cluster sizes has been confirmed by high resolution transmission electron microscopy (TEM) (ref. 8). The presence of the highly distorted lattice structures, with essentially immobile defect clusters and/or nanoscale ordered 


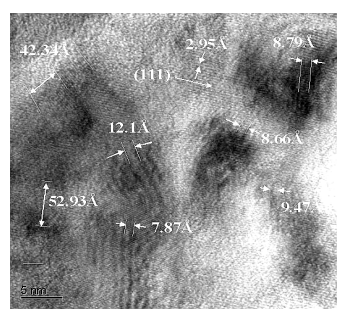

Plasma-sprayed $\mathrm{ZrO}_{2}-(\mathrm{Y}$, $\mathrm{Nd}, \mathrm{Yb})_{2} \mathrm{O}_{3}$

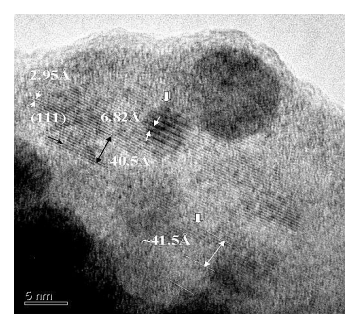

EB-PVD $\mathrm{ZrO}_{2}-(\mathrm{Y}$ $\mathrm{Nd}, \mathrm{Yb})_{2} \mathrm{O}_{3}$

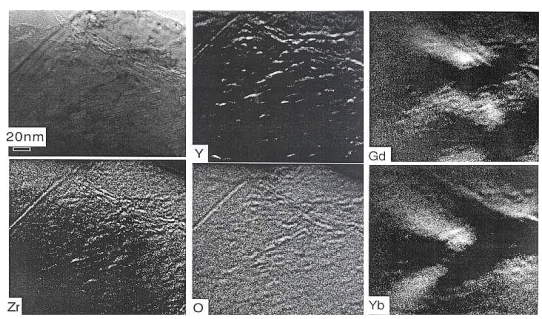

EELS elemental maps of EB-PVD $\mathrm{ZrO}_{2}^{-}$ $(\mathbf{Y}, \mathbf{G d}, \mathbf{Y b})_{2} \mathbf{O}_{3}$

(a)

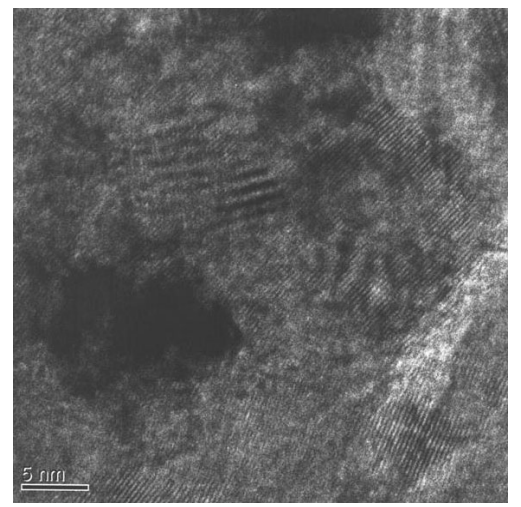

(b)

Figure 4.- - High-resolution TEM lattice image showing the defect clusters by moiré patterns in $\mathrm{ZrO}_{2}$-based and $\mathrm{HfO}_{2}$-based top coating systems. (a) $\mathrm{ZrO}_{2}$ coating systems; (b) $\mathrm{HfO}_{2}$ coating system.

phases, effectively reduce the mobile defect concentration and suppress the atomic mobility and mass transport, thus significantly improving the oxide sintering-creep resistance and mechanical properties. The defect clustering design is essential in reducing coating lattice and radiative thermal conductivity, and improving sintering-creep resistance. Improvements in mechanical properties such as fracture toughness and cyclic durability have been observed by the formation of complex nanoscale defect clusters and nanophase composites. Since a temperature gradient of 110 to $394{ }^{\circ} \mathrm{C}$ per $100 \mu \mathrm{m}\left(50\right.$ to $100{ }^{\circ} \mathrm{F}$ per $0.001 \mathrm{in}$.) coating thickness is important to advanced engines, the coatings must be designed with the optimal combination of performance characteristics required for the extended supersonics cruise mission. Figure 4 contains high resolution TEM lattice images of the defect clusters which form in the multi-oxide component $\mathrm{ZrO}_{2}$ - and $\mathrm{HfO}_{2}$-based coatings.

Thermal and environmental barrier coatings are being designed to protect $\mathrm{SiC} / \mathrm{SiC} \mathrm{CMC}$ combustor and turbine components by extending the $\mathrm{CMC}$ temperature capability to $1650^{\circ} \mathrm{C}\left(3000{ }^{\circ} \mathrm{F}\right)$ in oxidizing and water vapor containing combustion environments (refs. 9 and 10). To achieve the engine performance goals, the coatings must provide the thermal and environmental protection of Si-based components at the gas temperatures in excess of $1760^{\circ} \mathrm{C}\left(3200{ }^{\circ} \mathrm{F}\right)$, while maintaining the $\mathrm{CMC}$ substrate below its temperature limit, which is below $1316^{\circ} \mathrm{C}\left(2400^{\circ} \mathrm{F}\right)$. The coating consists of a multi-component zirconiaor hafnia-based oxide defect cluster top layer, a strain tolerant interlayer, a mullite/rare-earth silicate environmental barrier layer, and a ceramic oxide/rare earth silicate-mullite $(+\mathrm{Si})$ bond coat layer. The thermal and environmental barrier coating system provides an ultimate protective coating solution for silicon-based ceramic components exposed to very high temperatures and/or high flow gas velocities in water vapor-containing combustion and erosion environments. The advanced defect cluster oxide top layer possesses low intrinsic thermal conductivity and an extraordinarily high thermal stability at temperatures up to $3100{ }^{\circ} \mathrm{F}\left(1704{ }^{\circ} \mathrm{C}\right)$. The nanoscale oxide defect clustering and the thermodynamicallystable interfaces induce phonon scattering, resulting in a reduction in thermal radiative thermal conductivity within the coating system. Furthermore, the advanced interlayers impart a strain-tolerant 


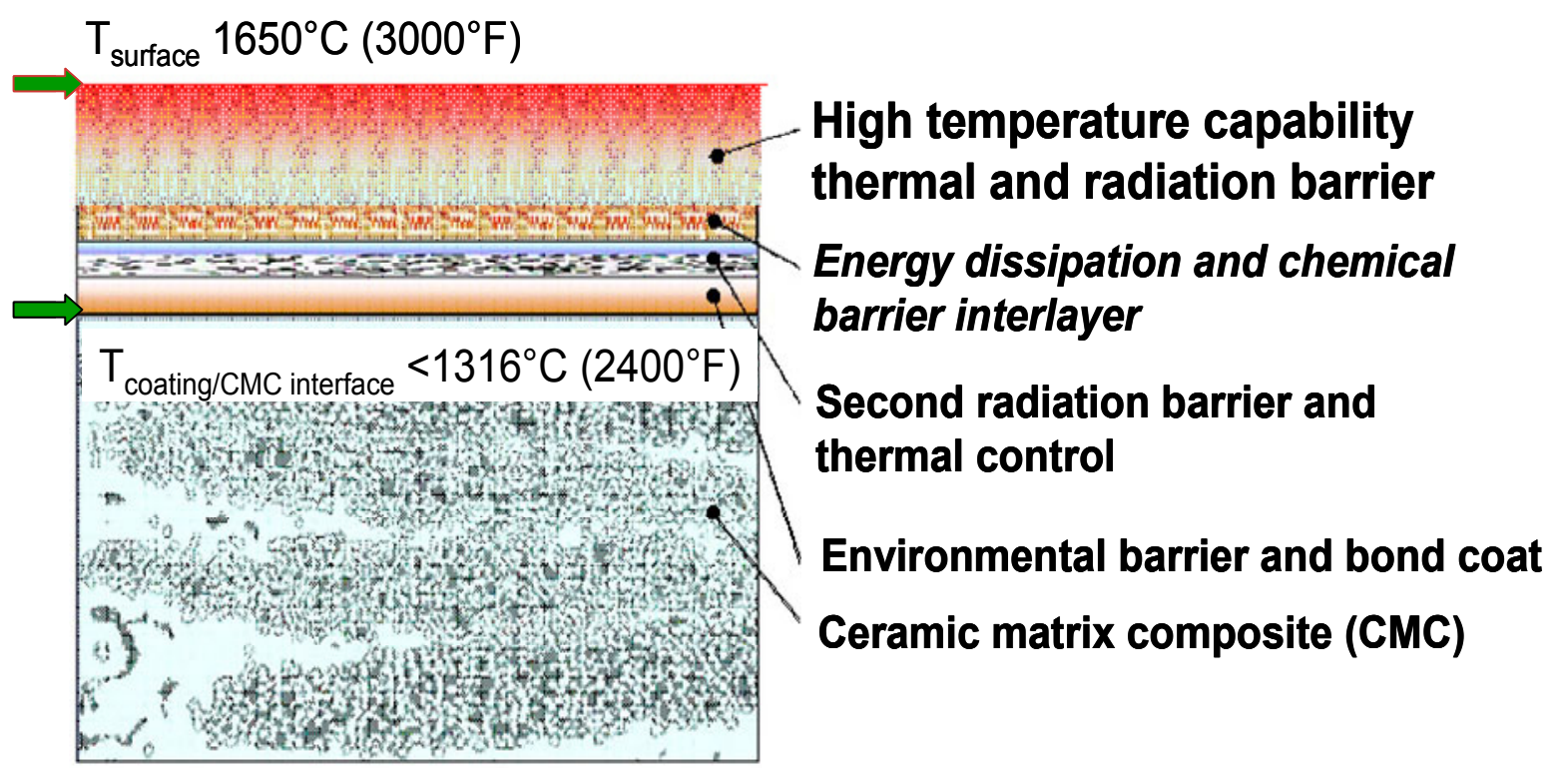

Figure 5.--Innovative multi-layer architecture which incorporates a high-temperature top coat, an advanced environmental barrier coat and a ceramic bond coat.

buffer between the top layer and the substrate (which can accommodate large thermal gradient strains through the coating system), enabling long-term coating and component durability. Figure 5 illustrates the revolutionary multilayer coating structure concept used to provide protection of Si-based ceramic and ceramic matrix composite engine components.

\section{Testing of Ceramic Coatings}

The development of low conductivity and high temperature stable ceramic barrier coatings requires testing techniques that can accurately evaluate thermal conductivity at high surface temperatures in the range of 1300 to $1400{ }^{\circ} \mathrm{C}$ for thermal barrier coatings, and up to $1650{ }^{\circ} \mathrm{C}\left(3000{ }^{\circ} \mathrm{F}\right)$ for the more advanced applications. A unique steady-state $\mathrm{CO}_{2}$ laser (wavelength $10.6 \mu \mathrm{m}$ ) heat-flux test rig is used to determine the thermal conductivity and cyclic durability of TEBC systems at high temperatures and under large thermal gradients across the coating. A schematic diagram showing the laser thermal conductivity rig is shown in figure 6 . The laboratory high-power $\mathrm{CO}_{2}$ laser heat-flux rig effectively simulates the engine heat-fluxes and thermal gradients. The laser heat-flux based testing approach can also be used to monitor the coating real-time thermal conductivity change kinetics, which is a critical aspect for the coating developments (refs. 6 and 7, and 9 to 15). The high velocity and high pressure burner rigs provide simulated engine gas flow, pressure and combustion environment conditions to evaluate the coating systems. The simulated combustion water-vapor environment, thermomechnical fatigue and erosion testing capabilities have also recently been incorporated into the laser heat-flux and burner rigs, as shown in figure 7. 


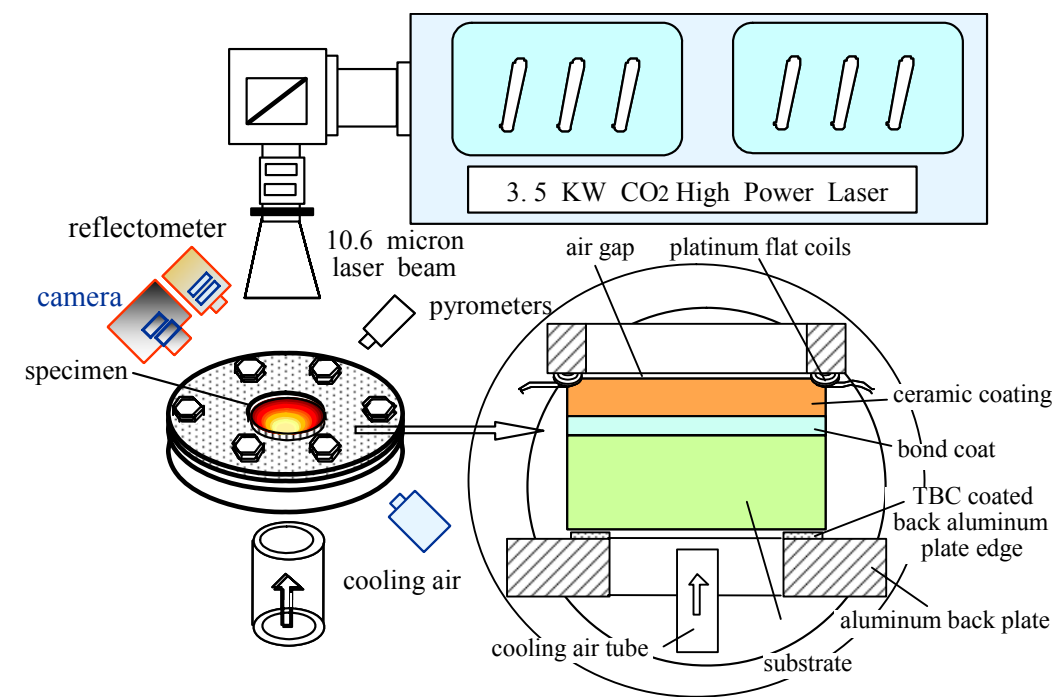

Figure 6.-Schematic diagram showing the laser heat-flux rig used to determine the thermal conductivity of ceramic TEBCs. During the test, the ceramic surface and the metal backside temperatures are measured by infrared pyrometers. The interfacial temperatures, and the actual heat-flux passing through the thermal barrier coating system, are therefore determined under the steady-state laser heating conditions by a one-dimensional (1-D) heat transfer model.

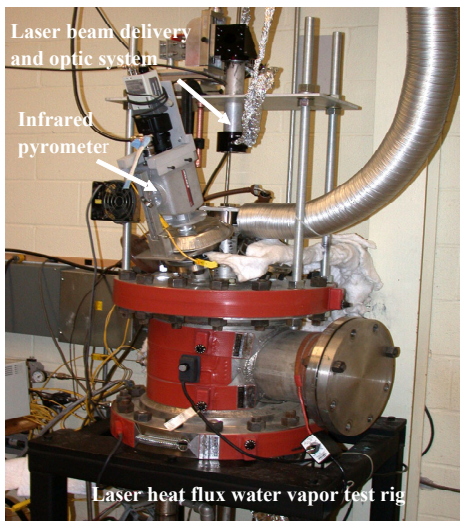

(a)

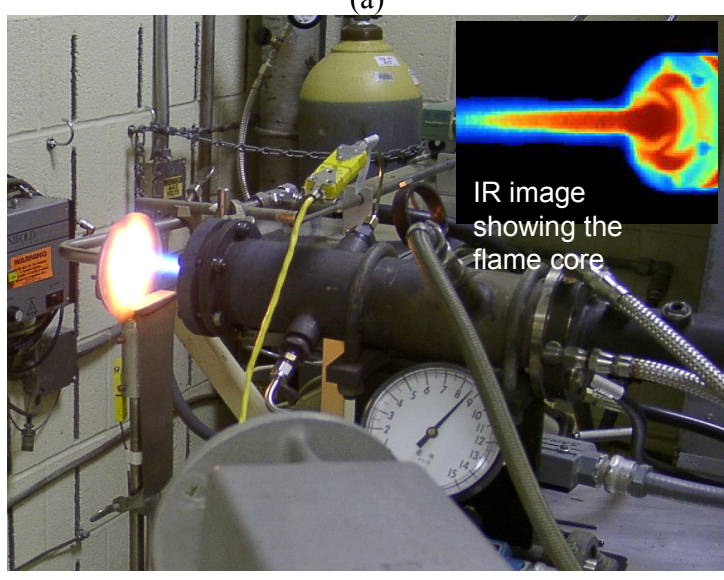

(c)
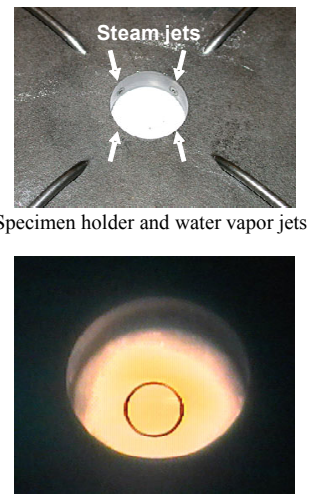

Specimen under testing

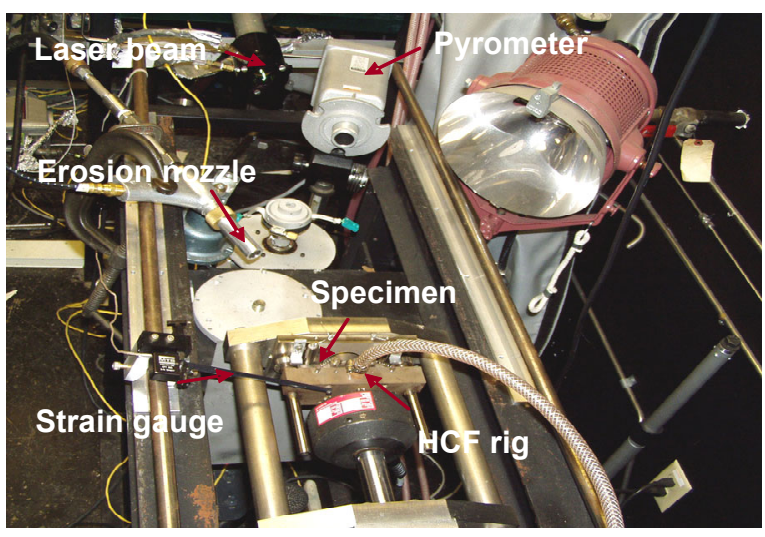

(b)

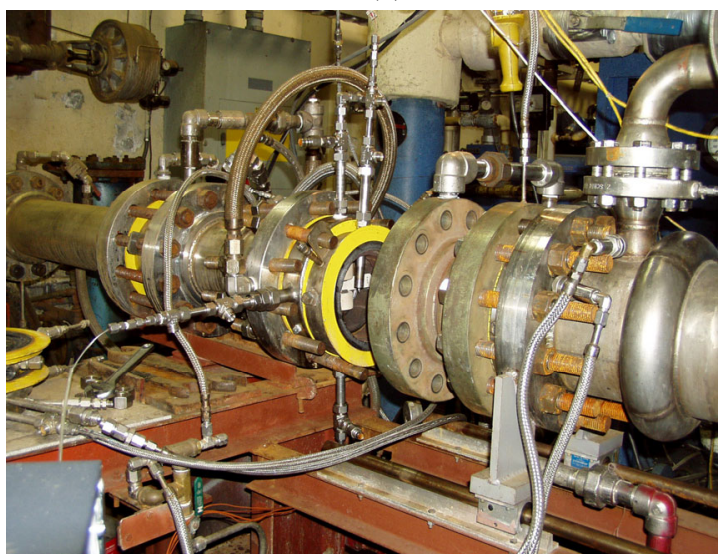

(d)

Figure 7.- Laser high-heat-flux and burner rig test rigs for simulated thermal gradient testing of thermal and environmental barrier coatings. (a) The laser heat-flux water vapor environment rig for advanced TEBC development; (b) Combined laser high heat flux, high cycle fatigue and erosion rig; (c) High velocity (Mach 0.3 to 0.7 ) burner erosion test rig. (d) High pressure burner rig with 6 to 10 atm pressure and up to $3000^{\circ} \mathrm{F}$ combustion gas environments. 


\section{Advanced Ceramic Coatings Development}

\section{Ceramic Thermal Barrier Coatings}

Advanced ceramic barrier coatings were designed using a multi-component defect-clustering approach to achieve the required low conductivity, high-temperature stability and improved durability. Selected oxide-cluster thermal barrier coating systems including $\mathrm{ZrO}_{2}-\mathrm{Y}_{2} \mathrm{O}_{3}-\mathrm{Nd}_{2} \mathrm{O}_{3}\left(\mathrm{Gd}_{2} \mathrm{O}_{3}, \mathrm{Sm}_{2} \mathrm{O}_{3}\right)$ $\mathrm{Yb}_{2} \mathrm{O}_{3}\left(\mathrm{Sc}_{2} \mathrm{O}_{3}\right)$ were synthesized, and their thermal conductivity, sintering behavior and cyclic durability were investigated at high temperatures. The advanced TBC systems, typically consisting of a 127 to $250 \mu \mathrm{m}$ ceramic top coat and a 75 to $120 \mu \mathrm{m}$ NiCrAlY or PtAl intermediate bond coat, were either plasma-sprayed or electron beam-physical vapor deposited (EB-PVD) on to $25.4 \mathrm{~mm}$ diameter disk substrates. The plasma-sprayed coatings were processed using pre-alloyed powders. The ceramic powders of selected compositions were first spray-dried, then plasma-reacted and spheroidized, and finally plasmasprayed as the coating form. The advanced EB-PVD coatings were deposited using pre-fabricated evaporation ingots made using the designed compositions.

Due to the relatively porous nature of the thermal barrier coating, thermal conductivity can increase significantly due to coating sintering and/or phase structure changes after a long-term thermal exposure. Therefore, evaluation of the initial and post-exposure thermal conductivities, and the rate-of-conductivityincrease is crucial in characterizing the coating's performance. Figure 8 shows the thermal conductivity kinetics of plasma-sprayed baseline $\mathrm{ZrO}_{2}-8 \mathrm{wt} \% \mathrm{Y}_{2} \mathrm{O}_{3}$ thermal barrier coating, determined using the steady-state laser heat-flux testing. The coating shows faster initial conductivity increase, due to the fast microcrack sintering rate at the initial stage.

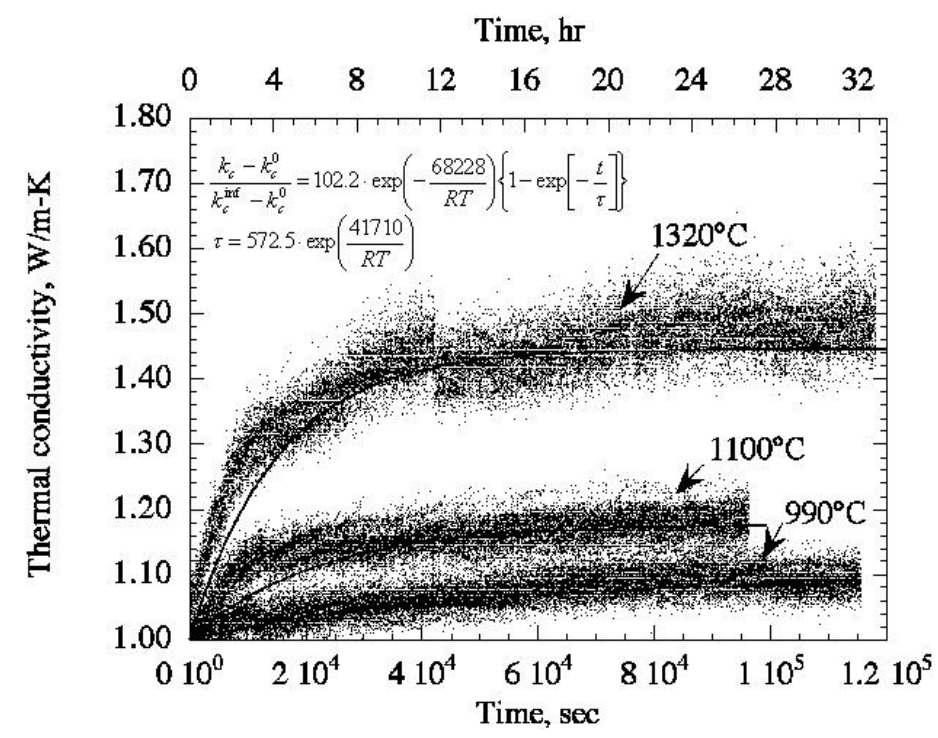

Figure 8.-Thermal conductivity change kinetics of plasmasprayed baseline $\mathrm{ZrO}_{2}-8 \mathrm{wt} \% \mathrm{Y}_{2} \mathrm{O}_{3}$ thermal barrier coatings, determined using steady-state laser heat-flux testing at moderate surface temperatures (pass-through heat flux $64 \mathrm{~W} / \mathrm{cm}^{2}$ ). Because a thermal conductivity gradient is expected through thickness of the ceramic coating under the thermal gradient conditions, the observed ceramic thermal conductivity increase reflects the overall effect of the conductivity change in the coating. 
After long-term testing, the coating conductivity reaches a plateau in the measuring conductivity. The coating thermal conductivity change kinetics for the baseline coating can be expressed as

$$
\begin{gathered}
k_{c}-k_{c}^{0}=102.2 \cdot \exp \left(-\frac{68228}{R T}\right)\left\{1-\exp \left[-\frac{t}{\tau}\right]\right\} \\
\tau=572.5 \cdot \exp \left(\frac{41710}{R T}\right)
\end{gathered}
$$

where $k_{c}$ is the coating thermal conductivity at any given time $t, k_{c}^{0}$ and $k_{c}^{\text {inf }}$ are ceramic coating thermal conductivity values at the initial time and at infinitely long times, respectively, $R$ is gas constant, and $\tau$ is relaxation time.

Figure 9 shows the sintering and creep strain kinetics of a baseline turbine airfoil $\mathrm{ZrO}_{2}-7 \mathrm{wt} \% \mathrm{Y}_{2} \mathrm{O}_{3}$ thermal barrier coating, derived from the surface wedge crack-opening displacements after testing for various times with temperature gradients (ref. 13). It can be seen that the sintering and creep strains are on the magnitude 2 percent approximately at $1316^{\circ} \mathrm{C}\left(2400{ }^{\circ} \mathrm{F}\right)$ following $1300 \mathrm{hr}$ exposure. The low resistant to sintering and creep of the baseline coating can result in accelerated cracking and delamination during the cyclic operation condition.

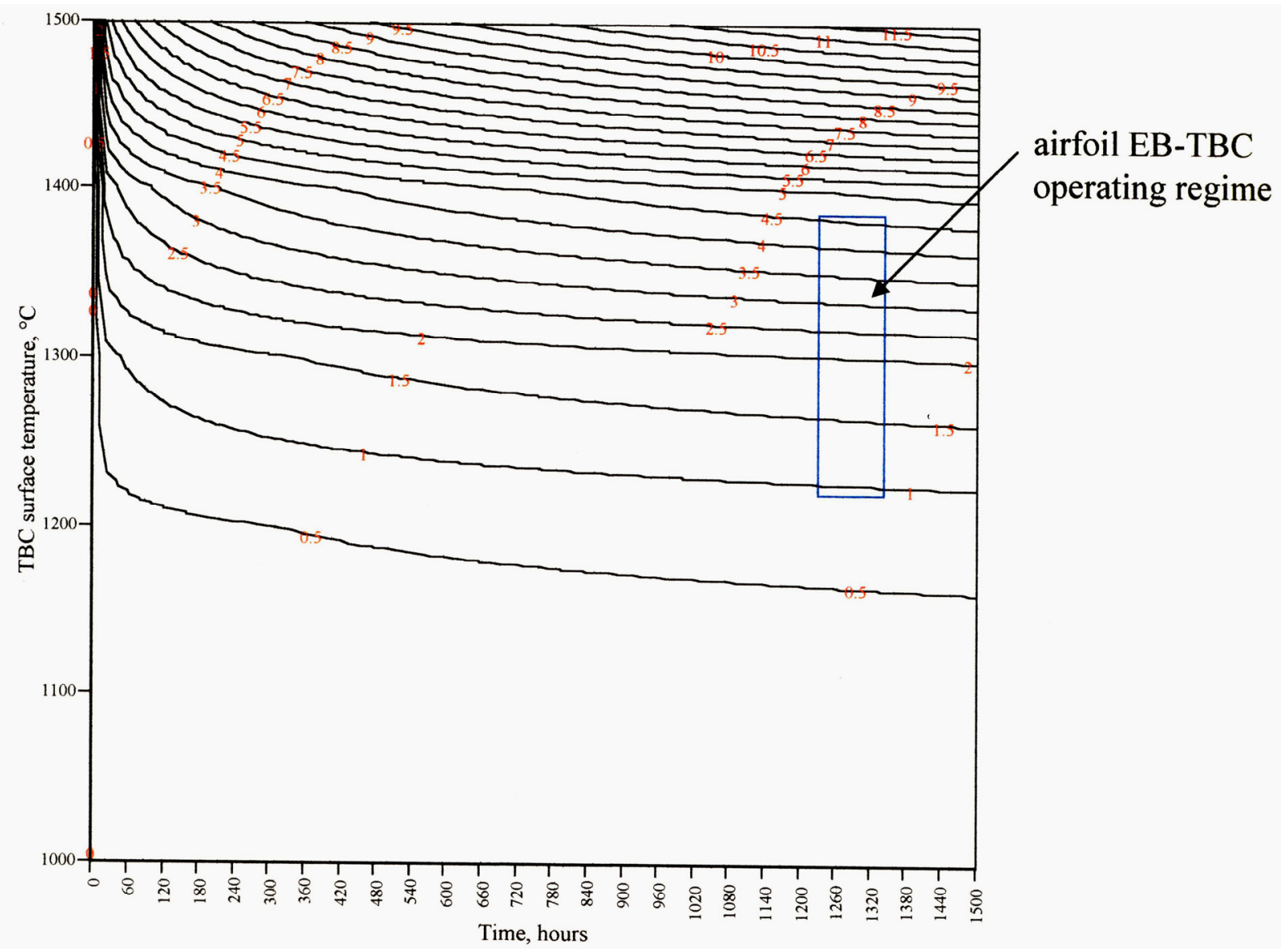

Figure 9.-Surface sintering and creep strains (\%) of an EB-PVD turbine airfoil $\mathrm{ZrO}_{2}-7 \mathrm{wt} \% \mathrm{Y}_{2} \mathrm{O}_{3}$ coating derived from laser high-heat-flux tests, using a heat flux of $220 \mathrm{~W} / \mathrm{cm}^{2}$ as functions of temperature and time. 
Figure 10 illustrates thermal conductivity behavior of advanced multi-component plasma-sprayed and EB-PVD thermal barrier coatings as a function of test time at high temperatures. The advanced oxide coatings were comprised of primarily $\mathrm{ZrO}_{2}-\mathrm{Y}_{2} \mathrm{O}_{3}$, and co-doped with additional paired rare earth oxides $\mathrm{Nd}_{2} \mathrm{O}_{3}-\mathrm{Yb}_{2} \mathrm{O}_{3}$ or $\mathrm{Gd}_{2} \mathrm{O}_{3}-\mathrm{Yb}_{2} \mathrm{O}_{3}$ (i.e., $\mathrm{ZrO}_{2}-(\mathrm{Y}, \mathrm{Nd}, \mathrm{Yb})_{2} \mathrm{O}_{3}$ and $\mathrm{ZrO}_{2}-(\mathrm{Y}, \mathrm{Gd}, \mathrm{Yb})_{2} \mathrm{O}_{3}$ coating systems). These coatings were found to possess much lower thermal conductivity and better temperature stability than the conventional baseline $\mathrm{ZrO}_{2}-7-8 \mathrm{wt} \% \mathrm{Y}_{2} \mathrm{O}_{3}$ coatings, due to the paired rare earth dopant addition and the defect cluster formation. From figure 11, it can be seen that depending on the test temperature and coating composition, a conductivity reduction of 50 to 66 percent is achieved in the advanced coating systems as compared to the $\mathrm{ZrO}_{2}-8 \mathrm{wt} \% \mathrm{Y}_{2} \mathrm{O}_{3}$ coatings.

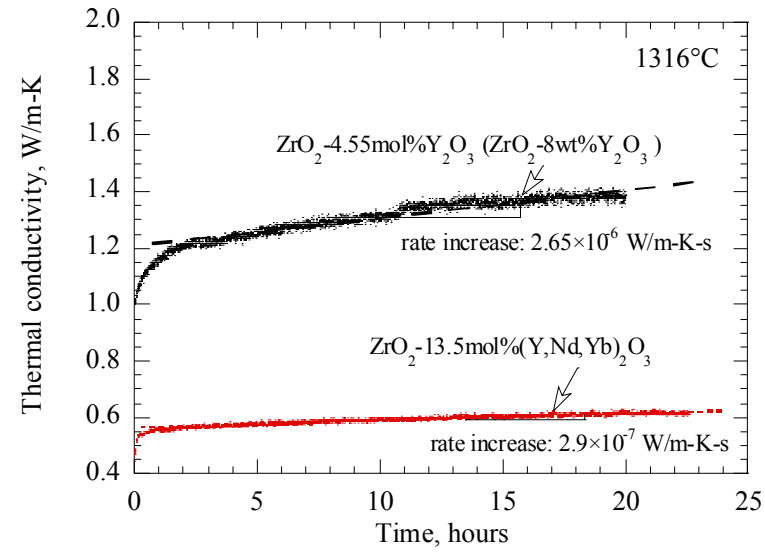

(a)

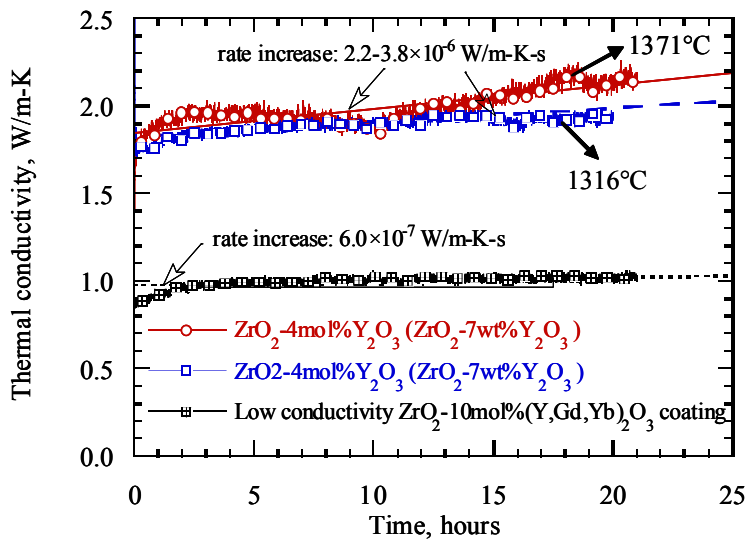

(b)

Figure 10.-Thermal conductivity of advanced multi-component plasma-sprayed and EB-PVD oxide cluster thermal barrier coatings, determined by laser heat-flux technique. (a) Plasma-sprayed coatings; (b) EB-PVD coatings. (a) Plasma-sprayed coating; (b) EB-PVD coating.

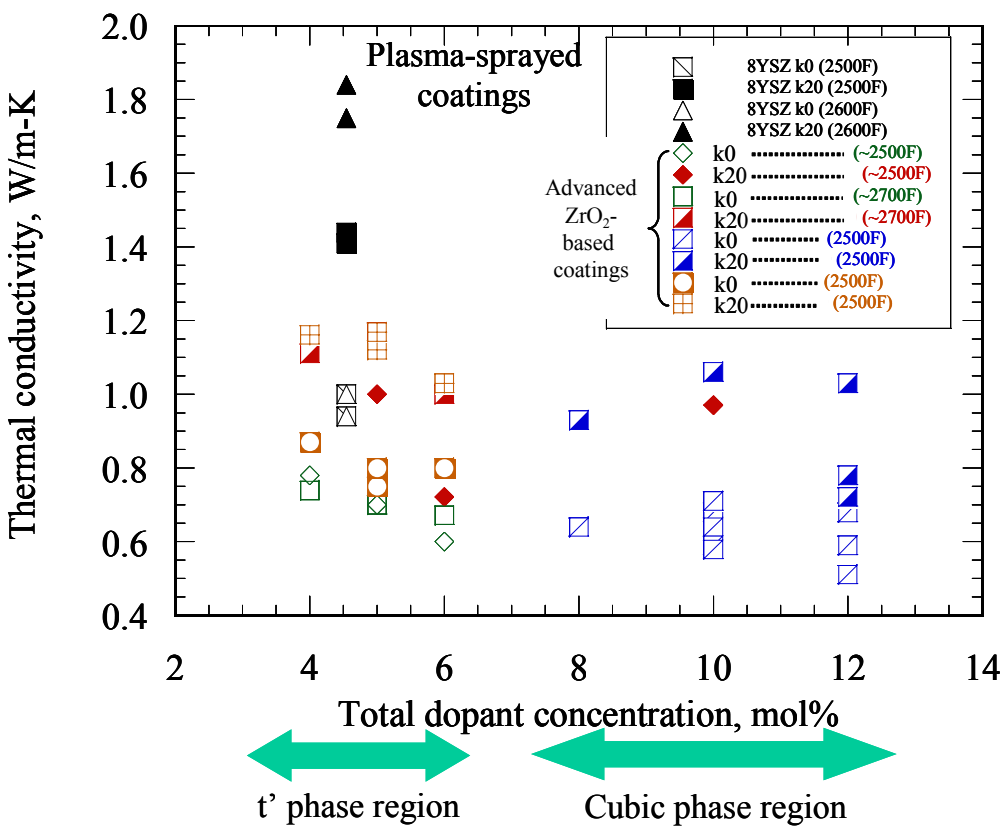

Figure 11.-Thermal conductivity of oxide-cluster thermal barrier coatings tested at high temperatures. Both tetragonal t' phase coatings and cubic phase $\mathrm{ZrO}_{2}$ cluster coatings showed significantly lower thermal conductivity than did the baseline $\mathrm{ZrO}_{2}-8 \mathrm{wt} \% \mathrm{Y}_{2} \mathrm{O}_{3}$ at higher temperatures. The $\mathrm{k} 0$ and $\mathrm{k} 20$ denote the conductivity values under asprocessed and $20 \mathrm{hr}$ steady-state tested conditions, respectively. 
The advanced low conductivity plasma-sprayed and EB-PVD coatings have demonstrated excellent cyclic durability and erosion resistance (ref. 11) with compositional and coating structural-design optimization. Figure 12 shows that both the advanced tetragonal phase composition coatings, and the cubic phase composition coatings with an interlayer system, achieved furnace cyclic oxidation durability comparable or better than the baseline $\mathrm{ZrO}_{2}-8 \mathrm{wt} \% \mathrm{Y}_{2} \mathrm{O}_{3}$ coatings. Figure 13 shows the advanced low conductivity turbine airfoil and combustor thermal barrier coating demonstrated long-term simulated engine high-heat-flux, high-thermal-gradient cyclic durability.

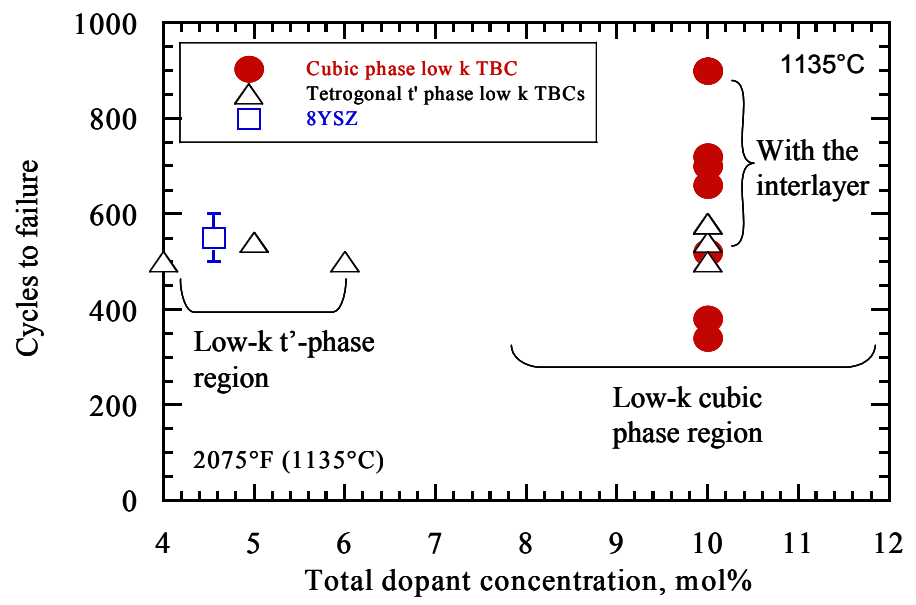

Figure 12.-Furnace cyclic oxidation behavior of plasmasprayed $\mathrm{ZrO}_{2}-(\mathrm{Y}, \mathrm{Gd}, \mathrm{Yb})_{2} \mathrm{O}_{3}$ thermal barrier coatings. The cyclic tests were conducted using 45 min hot time with 15 min cooling in air at $1138^{\circ} \mathrm{C}$. The tetragonal t'-phase composition low conductivity coatings achieved at least the baseline $\mathrm{ZrO}_{2-}$ $(7-8) \mathrm{wtY}_{2} \mathrm{O}_{3}$ life with a single layer architecture. The cubicphase composition low conductivity TBC durability, although inferior to the baseline coatings in a single layer configuration, can be significantly improved by an initial $\mathrm{ZrO}_{2}-8 \mathrm{wt} \mathrm{Y}_{2} \mathrm{O}_{3}$ or low $\mathrm{k}$ tetragonal t'-phase interlayer coating.

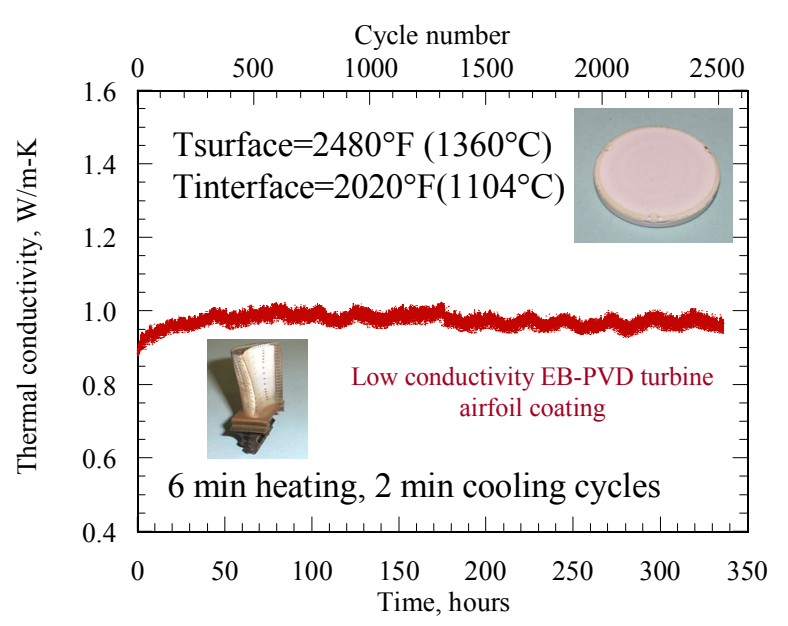

(a)

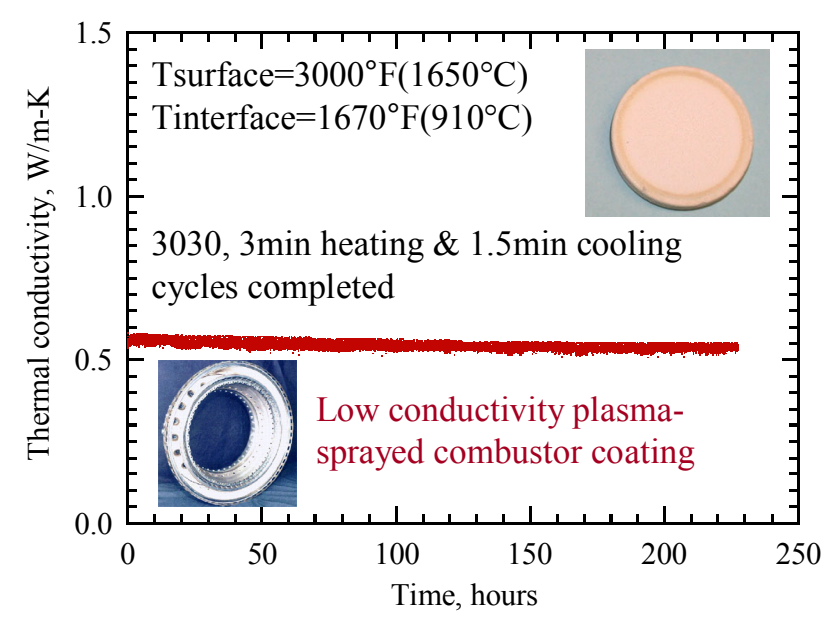

(b)

Figure 13.-An advanced low conductivity EB-PVD turbine airfoil and a plasma-sprayed combustor thermal barrier coatings demonstrated long-term cyclic durability in simulated engine high-heat-flux, high thermal gradient conditions at $1360^{\circ} \mathrm{C}\left(2480^{\circ} \mathrm{F}\right), 1650^{\circ} \mathrm{C}\left(3000^{\circ} \mathrm{F}\right)$, respectively. (a) EB-PVD low conductivity turbine airfoil thermal barrier coating; (b) Plasma-sprayed low conductivity combustor thermal barrier coating. 


\section{Ceramic Thermal and Environmental Barrier Coatings}

Multi-layerd and multi-component thermal and environmental barrier coatings based on $\mathrm{HfO}_{2}$ and rare earth mullite systems were developed for $\mathrm{SiC} / \mathrm{SiC} \mathrm{CMC} \mathrm{combustor} \mathrm{liner} \mathrm{and} \mathrm{vane} \mathrm{applications.} \mathrm{The}$ coating systems have shown improved phase stability, lower lattice and radiation thermal conductivity, and enhanced sintering and thermal stress resistance under the simulated engine heat-flux and thermal cycling conditions. This is largely due to the defect clustering structures which have been used to effectively promote the creation of the thermodynamically-stable oxide defect clusters and/or nano-phases within the coating systems (ref. 16), as compared to the baseline barium strontium aluminosilicate (BSAS) based environmental barrier coatings, i.e., BSAS/mullite+BSAS/Si, which has a temperature capability below $2400^{\circ} \mathrm{F}$ (refs. 17 and 18). The multi-component coatings have also demonstrated longterm cyclic durability and good water vapor stability. Figure 14 illustrates the durability exhibited by the multi-component $\mathrm{HfO}_{2}-18 \mathrm{~mol} \%(\mathrm{Y}, \mathrm{Gd}, \mathrm{Yb})_{2} \mathrm{O}_{3} / \mathrm{Gd}, \mathrm{Yb}$ and $\mathrm{Hf}$ modified mullite/mulite $+20 \% \mathrm{BSAS} / \mathrm{Si}$ EBC system, during the $1650{ }^{\circ} \mathrm{C}$ thermal gradient cycling testing. The coating system showed relatively low overall thermal conductivity, with no visual damage after the testing, demonstrating 300-hr long-term $1650{ }^{\circ} \mathrm{C}$ sintering stability and cyclic durability on $\mathrm{SiC} / \mathrm{SiC}$ ceramic matrix composite substrate under the thermal gradient cyclic testing conditions. As illustrated in figure 15, the $6 \mathrm{~atm}$ high pressure burner rig testing results indicated the excellent water vapor stability of the coating system in a simulated combustion environment. Figure 16 shows that a hybrid EB-PVD and plasma sprayed multi-component $\mathrm{HfO}_{2}$-based mullite-BSAS model turbine CMC coating system successfully performed at $3100^{\circ} \mathrm{F}$ and 100 thermal cycle laser high-heat-flux test (using $1 \mathrm{hr}$ cycles).

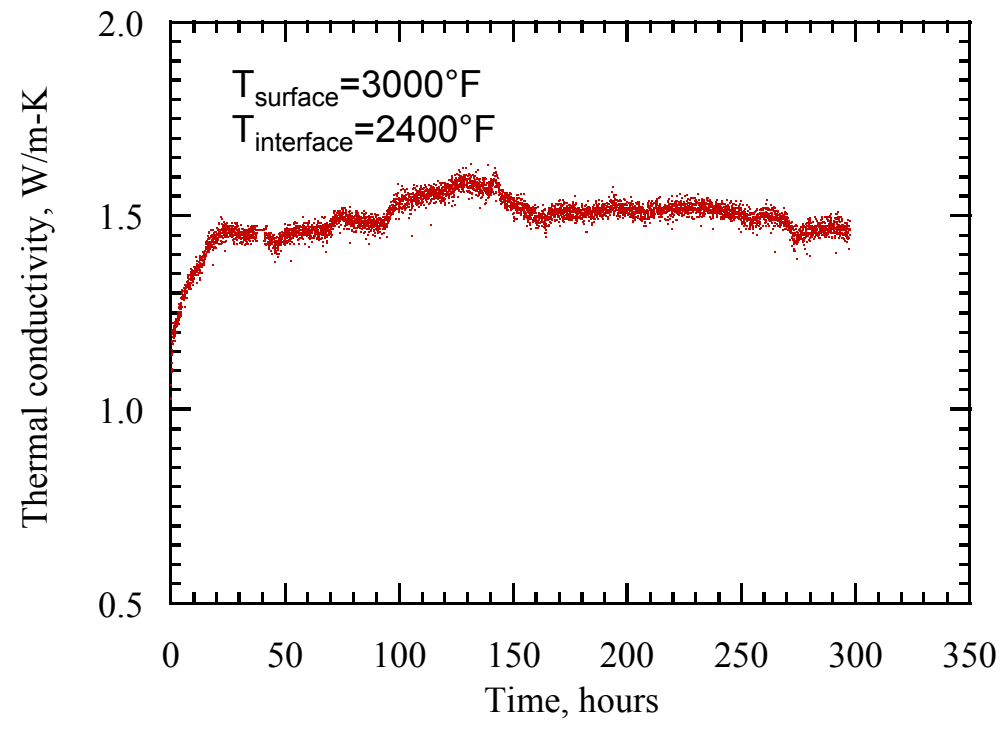

Figure 14.-Multi-component $\mathrm{HfO}_{2}-18 \mathrm{~mol} \%(\mathrm{Y}, \mathrm{Gd}, \mathrm{Yb})_{2} \mathrm{O}_{3} /$ rare earth mullite/ $\mathrm{HfO}_{2}$-based thermal and environmental barrier coating systems demonstrated $300 \mathrm{hr}$ long-term $3000^{\circ} \mathrm{F}$ sintering and cyclic durability on a $\mathrm{SiC} / \mathrm{SiC}$ ceramic matrix composite substrate under thermal gradient cyclic testing. 

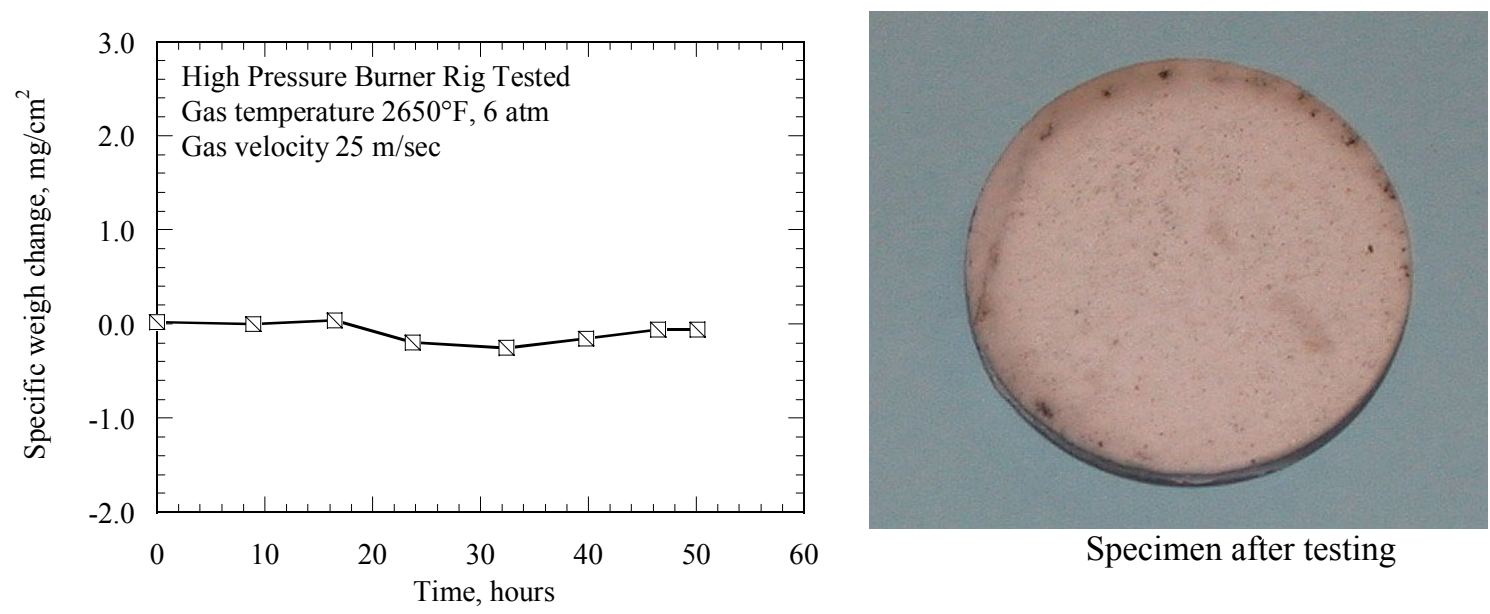

Specimen after testing

Figure 15.-Multi-component, multi-layerd $\mathrm{HfO}_{2}-(\mathrm{Y}, \mathrm{Gd}, \mathrm{Yb})_{2} \mathrm{O}_{3} /$ rare earth oxide doped mullite/Si thermal and environmental barrier coating systems demonstrated excellent water vapor stability and durability in the high pressure burner rig testing environments.
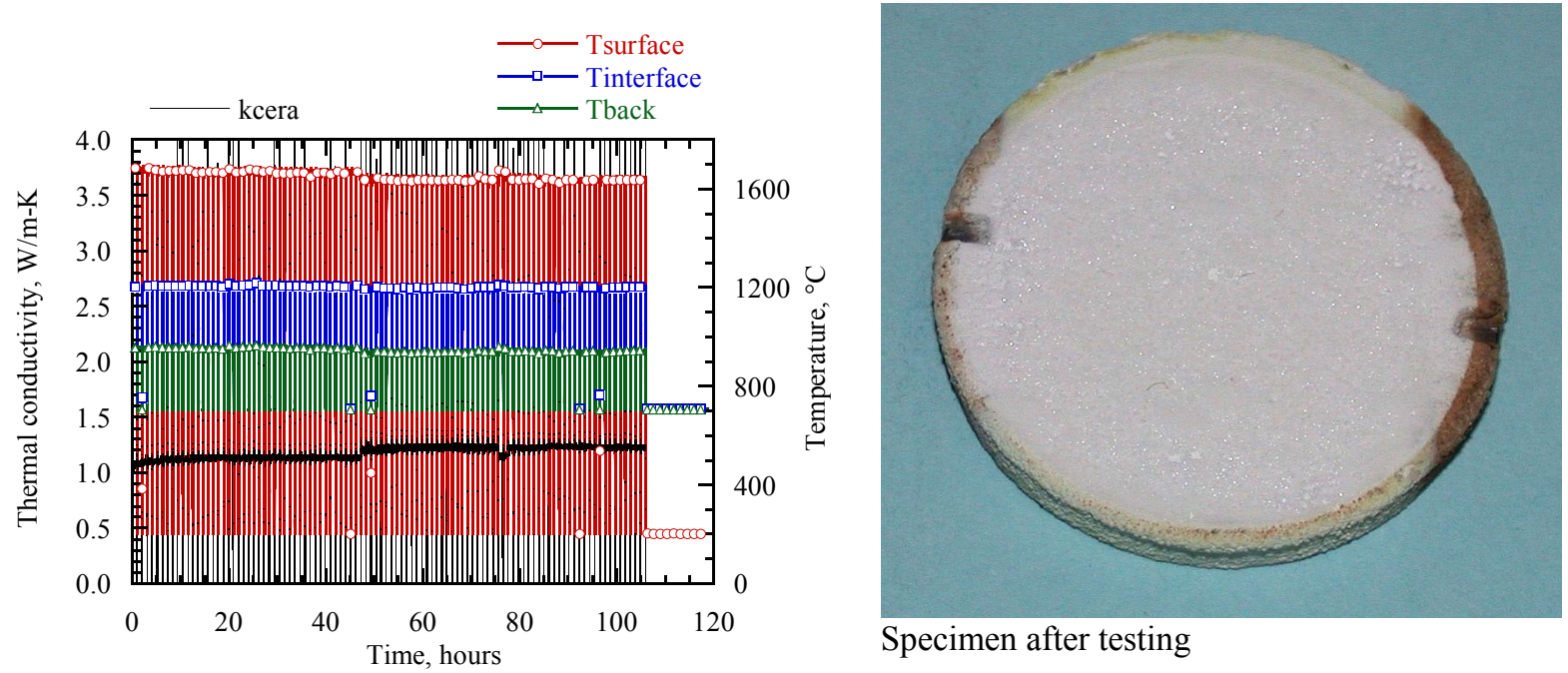

Specimen after testing

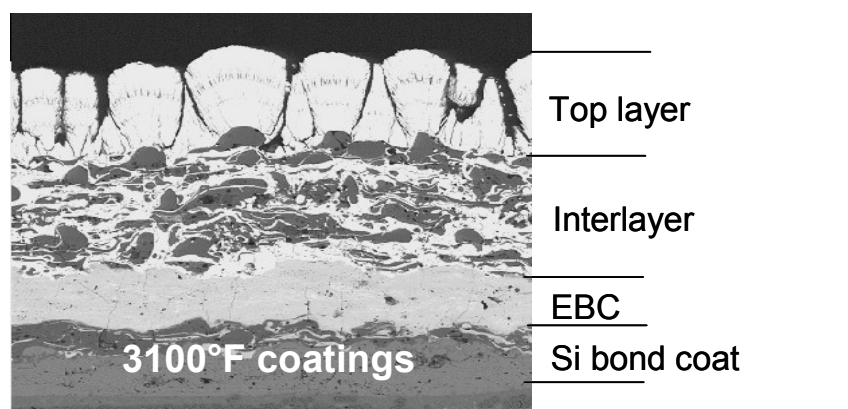

Cross-section micrograph

Figure 16.-An EB-PVD-plasma sprayed hybrid multi-component $\mathrm{HfO}_{2}$-based mullite-BSAS model turbine vane coating system successfully completed the total $100-1 \mathrm{hr}$ cycle laser heat flux testing at $3100^{\circ} \mathrm{F}$ (60 min hot, $3 \mathrm{~min}$ cool). 


\section{Concluding Remarks}

Thermal and environmental barrier coatings will play a crucial role in advanced gas turbine engines because of their ability to further increase engine operating temperature and reduce cooling requirements, thus help contributing to achieve engine emission and efficiency goals. Future coating systems must be designed with increased phase stability, lower thermal conductivity, and improved sintering and thermal stress resistance to effectively protect engine hot-section metallic and ceramic components. Advanced low conductivity TEBCs have been developed by incorporating multi-component oxide dopants into zirconia-yttria or hafnia-yttria to promote the formation of thermodynamically stable defect clusters within the coating structures. The advanced TEBC systems have demonstrated cyclic durability at temperatures up to $1650{ }^{\circ} \mathrm{C}$ which is far beyond the current state-of-the-art baseline $\mathrm{ZrO}_{2}-\mathrm{Y}_{2} \mathrm{O}_{3}$ thermal barrier and BSAS/mullite+BSAS environmental barrier coating capabilities. Modeling efforts are being pursued to understand the coating conductivity, sintering, and fracture, which can contribute to establishing design tools for the coating developments.

\section{References}

1. Michael T. Tong, Scott M. Jones and Philip C. Arcara, Jr., "A Probabilistic Assessment of NASA Ultra-Efficient Engine Technologies for a Large Subsonic Transport," Proceedings of Turbo Expo 2004, GT2004-53485.

2. Clayton L. Mayer, private communication.

3. Dongming Zhu, and Robert A. Miller, "Low Conductivity and Sintering Resistant Thermal Barrier Coatings," US Patent No. 6,812,176, 2004; US Patent No. 7,001,859, 2006; US Patent No. 7,186,466, 2007.

4. Dongming Zhu, and Robert A. Miller, "Multi-functionally graded environmental barrier coatings for Si-based ceramic components," Provisional patent application number: 60/712,605, August 26, 2005; US Patent Application No. 11/510 573, August 28, 2006.

5. Dongming Zhu and Robert A. Miller, "Low conductivity and high toughness tetragonal phase structured ceramic thermal barrier coatings," US Provisional Patent Application No.: 60/712,613, August 26, 2005. US Patent Application No. 11/510,574, August 28, 2006.

6. Dongming Zhu, and Robert A. Miller, "Thermal Conductivity and Sintering Behavior of Advanced Thermal Barrier Coatings," Ceramic Eng. Sci. Proc., vol. 23 (2002), pp. 457-468.

7. Dongming Zhu, and Robert A. Miller, "Development of Advanced Low Conductivity Thermal Barrier Coatings," International Journal of Applied Ceramic Technology, vol. 1 (2004), pp. 86-94.

8. Dongming Zhu, Yuan L. Chen and Robert A. Miller, "Defect Clustering and Nano-phase Structure Characterization of Multicomponent Rare-Earth Oxide Doped Zirconia-Yttria Thermal Barrier Coatings," Ceramic Eng. Sci. Proc., vol. 24 (2003). Also NASA TM-212480.

9. Dongming Zhu, and Robert A. Miller, "Hafnia-Based Materials Development for Advanced Thermal/Environmental Barrier Coating Applications," in Research and Technology 2003, NASA Glenn Research Center, NASA/TM-2004-212729, pp. 41-43.

10. Dongming Zhu, Narottam P. Bansal, and Robert A. Miller, "Thermal conductivity and Stability of Hafnia- and Zirconate-Based Materials for $1650{ }^{\circ} \mathrm{C}$ Thermal/Environmental Barrier Coating Applications," Ceramic Transactions, vol. 153 (2003). Also NASA TM-212544, 2003.

11. Dongming Zhu, and Robert A. Miller, "Thermal Conductivity Change Kinetics of Ceramic Thermal Barrier Coatings Determined by the Steady-State Laser Heat Flux Technique," in Research and Technology 1999, NASA Glenn Research Center, NASA TM-209639, pp. 29-31, March 2000.

12. Dongming Zhu, and Robert A. Miller, "Thermal Conductivity and Elastic Modulus Evolution of Thermal Barrier Coatings Under High Heat Flux Conditions," Journal of Thermal Spray Technology, vol. 9 (2000), pp. 175-180. 
13. Dongming Zhu, Robert A. Miller, Ben A. Nagaraj, and Robert W. Bruce, "Thermal Conductivity of EB-PVD Thermal Barrier Coatings Evaluated by a Steady-State Laser Heat Flux Technique," Surface and Coatings Technology, vol. 138 (2001), pp. 1-8.

14. Dongming Zhu, Narottam P. Bansal, Kang N. Lee, and Robert A. Miller, "Thermal Conductivity of Ceramic Coating Materials Determined by a Laser Heat Flux Technique," High Temperature Ceramic Matrix Composites IV, Proc. the 4th High Temperature Ceramic Matrix Composites Conference (HTCMC 4), Munich, Germany, Oct. 1-3 (2001), Edited by W. Krenkel, R. Naslain, and H. Schneider, Wiley-VCH, Verlag GmBH, Germany, 2001, pp. 262-267. Also NASA TM-211122, NASA Glenn Research Center, Cleveland, 2001.

15. Dongming Zhu, and Robert A. Miller, "Thermal Barrier Coatings for Advanced Gas Turbines," MRS Bulletin, vol. 25 (7) 2000, pp. 43-44.

16. Dongming Zhu, and Robert A. Miller, "Multicomponent Hafnia-Based Oxide Systems Developed, Characterized, and Evaluated for Advanced Ceramic-Matrix-Composite Barrier Coating Applications," in Research and Technology 2005, NASA Glenn Research Center, NASA/TM-2006214016, pp. 122-124.

17. Kang N. Lee, Dennis S. Fox, Jeffrey I. Eldridge, Dongming Zhu, Raymond C. Robinson, Narottam P. Bansal, and Robert A. Miller, "Upper Temperature Limit of Environmental Barrier Coatings Based on Mullite and BSAS," Journal of the American Ceramic Society, 86 [8] (2003), pp. 1299-1306.

18. Dongming Zhu, Sung R. Choi, Jeffrey I. Eldridge, Kang N. Lee, and Robert A. Miller, "Surface Cracking and Interface Reaction Associated Delamination Failure of Thermal and Environmental Barrier Coatings," NASA TM-212318, 2003. 


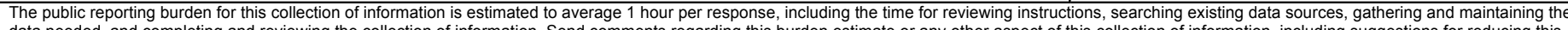

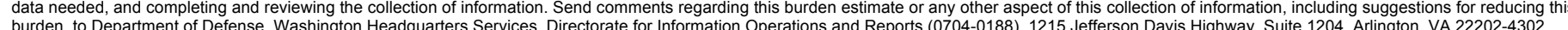

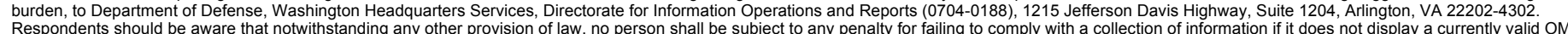
Respondents should be aware that notwithstanding any other provision of

PLEASE DO NOT RETURN YOUR FORM TO THE ABOVE ADDRESS.

\begin{tabular}{l|l|l}
\hline 1. REPORT DATE (DD-MM-YYYY) & 2. REPORT TYPE & 3. DATES COVERED (FrOm - To)
\end{tabular}

01-01-2008

4. TITLE AND SUBTITLE

Technical Memorandum

Thermal and Environmental Barrier Coating Development for Advanced Propulsion Engine

Systems

\section{5a. CONTRACT NUMBER}

5b. GRANT NUMBER

5c. PROGRAM ELEMENT NUMBER

6. AUTHOR(S)

Zhu, Dongming; Miller, Robert, A.; Fox, Dennis, S.

\section{5d. PROJECT NUMBER}

5e. TASK NUMBER

5f. WORK UNIT NUMBER

WBS 984754.02.07.03.05.01

\section{PERFORMING ORGANIZATION NAME(S) AND ADDRESS(ES)}

National Aeronautics and Space Administration

John H. Glenn Research Center at Lewis Field

8. PERFORMING ORGANIZATION

REPORT NUMBER

Cleveland, Ohio 44135-3191

E-16206

\section{SPONSORING/MONITORING AGENCY NAME(S) AND ADDRESS(ES)}

National Aeronautics and Space Administration

Washington, DC 20546-0001

and

U.S. Army Research Laboratory

Adelphi, Maryland 20783-1145

\section{DISTRIBUTION/AVAILABILITY STATEMENT}

Unclassified-Unlimited

Subject Categories: 24, 26, and 27

Available electronically at http://gltrs.grc.nasa.gov

This publication is available from the NASA Center for AeroSpace Information, 301-621-0390

\section{SUPPLEMENTARY NOTES}

\section{ABSTRACT}

Ceramic thermal and environmental barrier coatings (TEBCs) are used in gas turbine engines to protect engine hot-section components in the harsh combustion environments, and extend component lifetimes. Advanced TEBCs that have significantly lower thermal conductivity, better thermal stability and higher toughness than current coatings will be beneficial for future low emission and high performance propulsion engine systems. In this paper, ceramic coating design and testing considerations will be described for turbine engine high temperature and high-heat-flux applications. Thermal barrier coatings for metallic turbine airfoils and thermal/environmental barrier coatings for $\mathrm{SiC} / \mathrm{SiC}$ ceramic matrix composite (CMC) components for future supersonic aircraft propulsion engines will be emphasized. Further coating capability and durability improvements for the engine hot-section component applications can be expected by utilizing advanced modeling and design tools.

\section{SUBJECT TERMS}

Thermal barrier coatings; Environmental barrier coatings; Defect clustering; High stability oxides; Thermal conductivity; Sintering;

Creep; High heat flux; Erosion

\begin{tabular}{|c|c|c|c|c|}
\hline \multicolumn{3}{|c|}{ 16. SECURITY CLASSIFICATION OF: } & \multirow{2}{*}{$\begin{array}{l}\text { 17. LIMITATION OF } \\
\text { ABSTRACT } \\
\text { UU }\end{array}$} & \multirow{2}{*}{$\begin{array}{l}\text { 18. NUMBER } \\
\text { OF } \\
\text { PAGES } \\
20\end{array}$} \\
\hline $\begin{array}{l}\text { a. REPORT } \\
U\end{array}$ & $\begin{array}{l}\text { b. ABSTRACT } \\
U\end{array}$ & $\begin{array}{l}\text { c. THIS } \\
\text { PAGE } \\
\text { U }\end{array}$ & & \\
\hline
\end{tabular}

\section{SPONSORING/MONITORS ACRONYM(S) \\ 11. SPONSORING/MONITORING REPORT NUMBER \\ NASA/TM-2008-215040; ARL-TR-4368; AIAA-2007-2130}



